\title{
Poly(urethane-urea)s Based on Oligocarbonatediols Comprising Bis(carbamate)alkanes
}

\author{
Piotr PawŁowski, ${ }^{1}$ Adam Szymański, ${ }^{1}$ Janusz KozakiewiCz, ${ }^{2}$ \\ Jarosław PRZYBYLSKI ${ }^{2}$ and Gabriel ROKICKI ${ }^{1, \dagger}$ \\ ${ }^{1}$ Faculty of Chemistry, Warsaw University of Technology, Noakowskiego 3, 00-664 Warsaw, Poland \\ ${ }^{2}$ Industrial Chemistry Research Institute, Rydygiera 8, 01-793 Warsaw, Poland
}

(Received April 6, 2005; Accepted June 20, 2005; Published October 15, 2005)

\begin{abstract}
In this work the results of studies on the prepolymeric method of obtaining poly(urethane-urea)s from oligocarbonatediols and isophoronediisocyanate (IPDI), cured with water vapor, are presented. $\alpha, \omega$-Bis(2hydroxyethoxycarbonylamino)alkanes (dihydroxydiurethanes, DHDU) incorporated into the structure of oligocarbonatediols and as pseudo-chain extenders were used for the synthesis of prepolymers. The oligocarbonatediols were obtained by the thermal polymerization of trimethylene carbonate (TMC) using 1,3-propanediol and DHDU as initiators. The poly(urethane-urea)s obtained exhibited very good mechanical properties (e.g.: tensile strength of $45.5 \mathrm{MPa}$ and elongation at break up to 580\%). [DOI 10.1295/polymj.37.742]

KEY WORDS Poly(urethane-urea)s / Oligocarbonatediols / Isophoronediisocyanate / Trimethylene Carbonate / Dihydroxydiurethanes /
\end{abstract}

Polyurethanes based on oligocarbonatediols are known since 1990s. They are characterized by oxidative and hydrolytic stability, and therefore they can be used to obtain materials for biomedical applications. ${ }^{1,2}$ Polycarbonate fragments indicate a relatively high hydrolytic stability. The hydrolysis of oligocarbonates leads to the formation of hydroxyl groups and $\mathrm{CO}_{2}$, i.e. products which do not catalyze further hydrolysis.

Soft segments of polyurethanes in the form of aliphatic carbonate oligomers are usually obtained by the condensation method from 1,6-hexanediol and phosgene or carbonate acid esters. ${ }^{3,4}$

Oligocarbonatediols for polyurethanes can also be obtained by copolymerization of oxiranes with carbon dioxide in the presence of organozinc catalysts. ${ }^{5}$ In order to decrease the molecular weight of such aliphatic polycarbonates, high-molecular weight poly(propylene carbonate)s were subjected to transesterification reaction with 1,4-butanediol or 1,6-hexanediol., The formation of a fraction of the oligomers terminated with less reactive secondary $\mathrm{OH}$ groups was a disadvantage of this method. The removal of the remaining polymerization and transesterification catalysts from the product caused an additional difficulty.

Six-membered cyclic carbonates homopolymerize, contrary to five-membered carbonates. During the polymerization of six-membered cyclic carbonates proceeding according to the cationic mechanism, decarboxylation takes place, and ether bonds are formed. The presence of ether bonds in the structure of soft polyurethane segments decreases the oxidation resistance of polyurethane. ${ }^{8}$
In the case of anionic polymerization of cyclic six-membered carbonates decarboxylation does not occur; however, in the post-reaction mixture some amount of the unreacted monomer can be present. The process is most often initiated by potassium, sodium and lithium alkoxides. ${ }^{9}$ Amine initiators, most often hypernucleophilic derivatives of pyridine or other cyclic amines, e.g. 4- $\mathrm{N}, \mathrm{N}$-dimethylaminopyridine (DMAP) and 1,8-diazabicyclo[5,4,0]undec-7-ene (DBU) are also used as catalysts of the anionic polymerization. ${ }^{10}$

The coordination polymerization of six-membered carbonates is carried out in the presence of organometallic catalysts containing $\mathrm{Zn}, \mathrm{Sn}, \mathrm{Al}$ atoms; tin(II) octoate is most often used. ${ }^{11}$ Admittedly, the polymerization is not accompanied by decarboxylation and no ether groups are formed, but part of the polymer chains have a terminal $\mathrm{OH}$ group protected by the acid radical of the catalyst. ${ }^{12}$

Some cyclic six-membered carbonates, like trimethylene carbonate (TMC), undergo spontaneous thermal polymerization. ${ }^{13}$ Kricheldorf suggests that at elevated temperature a zwitterion is formed, of which the alkoxide anion initiates the chain growth according to the anionic mechanism (Scheme 1).

The formation of ether groups during the enzymatic polymerization of cyclic carbonates carried out in the presence of lipase enzyme Canadida Antartica was not observed. ${ }^{14}$ The yield and molecular weight of the polycarbonate obtained with an enzymatic catalyst very strongly depend on the reaction conditions.

Taking the above into consideration, we used the

${ }^{\dagger}$ To whom correspondence should be addressed (Tel: +48-22-660-7562, FAX: +48-22-628-2741, E-mail: HTgabro@ch.pw.edu.pl). 


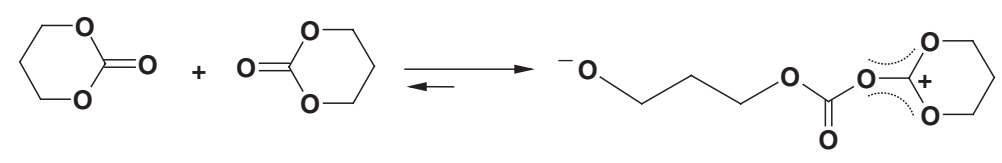

Scheme 1.

thermal method of polymerization to obtain oligo(trimethylene carbonate)s which can be applied in the oxidative resistant polyurethane synthesis. The resultant oligomers are terminated on both sides with hydroxyl groups and do not contain ether groups in their structure. The non-necessity of using catalysts is an additional advantage of this method.

Little information can be found in the literature on the application of oligo(trimethylene carbonate)s in the synthesis of polyurethanes. Macrodiols obtained from TMC were applied for the preparation of polyurethanes using 4,4'-diphenylmethane diisocyanate (MDI). ${ }^{15}$ Polyurethanes were obtained in a one-step process using 1,4-butanediol and 1,3-propanediol as chain extenders.

In this work we present the results of studies on the application of oligo(trimethylene carbonate) diols to obtain poly(urethane-urea)s using water vapor as a curing agent. The effect of the presence of $\alpha, \omega$-bis(2-hydroxyethoxycarbonylamino)alkanes (DHDU) in the oligocarbonate diols on the poly(urethane-urea)s mechanical properties is also presented. The poly(urethane-urea)s obtained may find application in the production of biocompatible medical materials.

\section{EXPERIMENTAL}

\section{Materials}

Ethylene carbonate, dimethyl carbonate, 1,3-propanediol, 4-N,N-dimethylaminopyridine, 1,2-diaminoethane, 1,6-diaminohexane, isophoronodiisocyanate (IPDI) (Aldrich), Chirazyme L-2 enzyme (Roche), zinc acetate, methylene chloride, THF (POCh Gliwice, Poland) were used without additional purification.

\section{Measurement Methods}

${ }^{1} \mathrm{H}$ NMR and ${ }^{13} \mathrm{C}$ NMR spectra were recorded by means of a Varian VXR $400 \mathrm{MHz}$ spectrometer. Deuterated solvents were used and tetramethylsilane served as internal standard. IR spectra were measured using a Biorad FT IR spectrophotometer. Samples for analysis were prepared in the form of pellets with $\mathrm{KBr}$. The chemical structure of oligocarbonatediols was studied by means of a MALDI-TOF mass spectrometer (Kratos Kompact MALDI 4 V5.2.1 using 2,5-dihydroxybenzoic acid as the matrix). The apparatus was equipped with a nitrogen laser of $337 \mathrm{~nm}$ wavelength and length impulses of $3 \mathrm{~ns}$. For each sample the spectrum was recorded based on 200 impulses. The samples were prepared by dissolution of the studied polymer in THF and mixing it with a solution of 2,5-dihydroxybenzoic acid used as a MALDI-TOF matrix. DSC studies were performed in the temperature range from $-120^{\circ} \mathrm{C}$ to $+60^{\circ} \mathrm{C}$ using a Perkin Elmer Pyris 1 calorimeter at a heating rate of $20^{\circ} \mathrm{C} / \mathrm{min}$ for samples of $10-25 \mathrm{mg}$ mass.

\section{Synthesis of Trimethylene Carbonate $(T M C)^{16}$}

In a $500 \mathrm{~cm}^{3}$ round-bottomed flask $110 \mathrm{~g}(1.45 \mathrm{~mol})$ of 1,3-propanediol, $156 \mathrm{~g}(1.73 \mathrm{~mol})$ of dimethyl carbonate and $3.68 \mathrm{~g}(0.02 \mathrm{~mol})$ of zinc acetate were placed. In the first stage the reaction was carried out under a reflux condenser for $30 \mathrm{~min}$. In the second stage the methanol formed was distilled off. The polycondensation progress was monitored by collecting samples of the reaction mixture and observing changes in the absorption band derived from hydroxyl groups by means of infrared spectroscopy and observing the amount of methanol formed. Then, the excess of dimethyl carbonate was distilled off and the reaction was carried out under reduced pressure $(2 \mathrm{mmHg})$ at $133-135^{\circ} \mathrm{C}$ for $4 \mathrm{~h}$. After this time the temperature of the bath was increased to $240^{\circ} \mathrm{C}$ and the depolymerization process was carried out with distilling off the product. The crude product obtained $(120.1 \mathrm{~g}$, $81 \%$ yield) was then crystallized from THF. $108 \mathrm{~g}$ (73\% yield) of white crystals of m.p. $46-47^{\circ} \mathrm{C}$ were obtained.

${ }^{1} \mathrm{H} \mathrm{NMR} \quad 400 \mathrm{MHz} \quad\left(\mathrm{CDCl}_{3}\right) \quad \delta \quad(\mathrm{ppm})=2.11 \quad(\mathrm{~m}$, $\left.\mathrm{OC}(\mathrm{O}) \mathrm{OCH}_{2} \mathrm{CH}_{2}\right), 4.42$ (t, $\mathrm{OC}(\mathrm{O}) \mathrm{OC}_{2} \mathrm{CH}_{2}, \quad J=$ $5.6 \mathrm{~Hz})$.

\section{Synthesis of Oligocarbonatediol from Trimethylene Carbonate and 1,3-Propanediol}

Polymerization Thermally Initiated. In a $150 \mathrm{~cm}^{3}$ round-bottomed flask equipped with a mechanical stirrer and thermometer $52 \mathrm{~g}(0.51 \mathrm{~mol})$ of trimethylene carbonate and $2.72 \mathrm{~g}(0.036 \mathrm{~mol})$ of 1,3-propanediol were placed. The reaction system was heated in a nitrogen atmosphere for $24 \mathrm{~h}$. The reaction progress was monitored using IR spectrophotometry observing the absorption band at $760 \mathrm{~cm}^{-1}$ characteristic for the cyclic carbonate skeleton vibrations. $62.6 \mathrm{~g}$ of liquid, colorless oligo(trimethylene carbonate) of $M_{\mathrm{n}}=$ $1500 \mathrm{Da}$ was obtained.

${ }^{1} \mathrm{H}$ NMR $400 \mathrm{MHz}\left(\right.$ DMSO- $\left.d_{6}\right) \delta(\mathrm{ppm})=1.30(\mathrm{~m}$, 
$\left.\mathrm{OCH}_{2} \underline{\mathrm{H}}_{2}\right) ; 3.51\left(\mathrm{~m}, 4 \mathrm{H}, \mathrm{HOC} \underline{\mathrm{H}}_{2}\right), 4.10\left(\mathrm{~m}, \mathrm{OC}_{2}-\right.$ $\mathrm{CH}_{2}$ ).

FT IR (KBr): 3365, 2960, 1747, 1470, 1245, 1034, $933,791 \mathrm{~cm}^{-1}$.

Elemental analysis: C 46.77, H 6.54.

Polymerization Initiated in a Microwave Oven. $15 \mathrm{~g}(0.15 \mathrm{~mol})$ of trimethylene carbonate and $0.8 \mathrm{~g}$ $(0.01 \mathrm{~mol})$ of 1,3 -propanediol were placed in a glass ampoule. The polymerization was carried out at $120 \pm$ $10^{\circ} \mathrm{C}$ in nitrogen atmosphere in a MAXIDIGEST MX-350 (Prolabo) microwave furnace for $10 \mathrm{~min}$. $14.6 \mathrm{~g}$ of liquid, colorless oligo(trimethylene carbonate) of $M_{\mathrm{n}}=1300 \mathrm{Da}$ were obtained.

Polymerization in the Presence of Chirazyme L-2 Lipase. $\quad 30 \mathrm{~g}(0.29 \mathrm{~mol})$ of trimethylene carbonate, $1 \mathrm{~g}$ of Chirazyme L-2 enzyme immobilized on a polymer support and $20 \mathrm{~cm}^{3}$ of tetrahydrofuran were placed in a glass ampoule. The polymerization was carried out at $60^{\circ} \mathrm{C}$ in nitrogen atmosphere. The reaction course was monitored by means of IR spectroscopy. The reaction was carried out for $96 \mathrm{~h}$ reaching monomer conversion of $80 \%$. After reaction completion the enzyme was filtered off and the solvent was removed under reduced pressure. $20.7 \mathrm{~g}$ of oligo(trimethylene carbonate) of $M_{\mathrm{n}}=1650$ Da were obtained.

Synthesis of $\alpha, \omega$-Bis(2-hydroxyethoxycarbonylamino)alkanes from Ethylene Carbonate and $\alpha, \omega-D i$ amines

Synthesis of 1,6-Bis(2-dihydroxyethoxycarbonylamino)hexane from Ethylene Carbonate and 1,6-Diaminohexane. 1,6-Diaminohexane (3.05 g; 0.026 $\mathrm{mol})$, ethylene carbonate $(4.58 \mathrm{~g} ; 0.052 \mathrm{~mol})$ and 25 $\mathrm{cm}^{3}$ of methylene chloride were placed in a 50.0 $\mathrm{cm}^{3}$ flask. A white precipitate isolated after $30 \mathrm{~min}$. However, the reaction mixture was stirred in total for $24 \mathrm{~h}$ at $38^{\circ} \mathrm{C}$. The product was filtered off and washed with methylene chloride, and then dried at $50{ }^{\circ} \mathrm{C}$. A white product of m.p. $89-90^{\circ} \mathrm{C}$ was obtained. Yield $6.60 \mathrm{~g}(87 \%)$.

${ }^{1} \mathrm{H}$ NMR $400 \mathrm{MHz}\left(\mathrm{DMSO}-d_{6}\right): \delta(\mathrm{ppm})=1.21(\mathrm{~m}$, $\left.4 \mathrm{H}, \mathrm{NH}\left(\mathrm{CH}_{2}\right)_{2} \mathrm{CH}_{2}\right) ; 1.34$ (m, 4H, $\left.\mathrm{NHCH}_{2} \mathrm{CH}_{2}\right) ; 2.92$ $\left(\mathrm{m}, 4 \mathrm{H}, \mathrm{NHC}_{2}\right) ; 3.50\left(\mathrm{~m}, 4 \mathrm{H}, \mathrm{HOC}_{2}\right) ; 3.92(\mathrm{t}, 4 \mathrm{H}$, $\left.\mathrm{C}_{2} \mathrm{OC}(\mathrm{O}), J=4.8 \mathrm{~Hz}\right) ; 4.71$ (bs, $\left.1 \mathrm{H}, \underline{\mathrm{HOCH}}_{2}\right) ; 6.73$ and 7.09 (bs and t, $2 \mathrm{H}, \mathrm{OC}(\mathrm{O}) \mathrm{NHCH}_{2}, J=5.6 \mathrm{~Hz}$ ). FTIR (KBr): 1687, 1535, 1464, 1454, 1270, 1100.

$\mathrm{C}_{12} \mathrm{H}_{24} \mathrm{~N}_{2} \mathrm{O}_{6}(292.33 \mathrm{~g} / \mathrm{mol})$; Calcd.: C 49.30, H 8.28, N 9.58; Found: C 48.82, H 8.41, N 9.27.

Synthesis of 1,2-Bis(hydroxyethoxycarbonylamino)ethane from Ethylene Carbonate and 1,2-Diaminoethane. The reaction was carried out as described above, using 1,2-diaminoethane (1.95 g; $0.0325 \mathrm{~mol})$, ethylene carbonate $(5.72 \mathrm{~g} ; 0.065 \mathrm{~mol})$ and $\mathrm{CH}_{2} \mathrm{Cl}_{2}$ $\left(50 \mathrm{~cm}^{3}\right)$. White crystals of m.p. $84-85^{\circ} \mathrm{C}$ were obtained. Yield $7.2 \mathrm{~g} \mathrm{(94 \% ).}$
${ }^{1} \mathrm{H}$ NMR $400 \mathrm{MHz}\left(\right.$ DMSO- $\left.d_{6}\right): \delta(\mathrm{ppm})=2.92(\mathrm{~s}$, $\left.4 \mathrm{H}, \mathrm{NHCH}_{2}\right) ; 3.50$ (t, $\left.4 \mathrm{H}, \mathrm{CH}_{2} \mathrm{O}, J=4.8 \mathrm{~Hz}\right) ; 3.92$ $\left(\mathrm{t}, \quad 4 \mathrm{H}, \quad \mathrm{HOCH}_{2} \underline{\mathrm{C}}_{2}, J=4.8 \mathrm{~Hz}\right) ; 4,71 \quad(\mathrm{~s}, 2 \mathrm{H}$, $\left.\mathrm{HOCH}_{2}\right) ; 6.73$ and $7.09(\mathrm{~m}, 2 \mathrm{H}, \mathrm{OC}(\mathrm{O}) \mathrm{NH})$. FTIR (KBr): 1687, 1537, 1467, 1455, 1271, 1105. $\mathrm{C}_{8} \mathrm{H}_{16} \mathrm{~N}_{2} \mathrm{O}_{6}(236.23 \mathrm{~g} / \mathrm{mol}):$ Calcd: C 40.68 , H 6.83, N 11.86; Found: C 40.12, H 6.89, N 11.19.

Synthesis of Oligocarbonatediol from Trimethylene Carbonate and $\alpha, \omega$-Bis(2-hydroxyethoxycarbonylamino)alkanes

In a $50 \mathrm{~cm}^{3}$ flask, 1,2-bis(2-hydroxyethoxycarbonylamino)ethane $(2.0 \mathrm{~g}, 0.0086 \mathrm{~mol})$ and trimethylene carbonate $(11.2 \mathrm{~g}, 0.11 \mathrm{~mol})$ were placed. The polymerization in bulk was carried out under nitrogen atmosphere at $110^{\circ} \mathrm{C}$ for $24 \mathrm{~h}$. The reaction course was monitored by means of infrared spectroscopy observing the decay of the absorption band at $760 \mathrm{~cm}^{-1}$ characteristic for skeleton vibrations of cyclic carbonate. $12.1 \mathrm{~g}$ of oligocarbonatediol of molecular weight 1490 was obtained; the molecular weight was estimated based on ${ }^{1} \mathrm{H}$ NMR spectra.

Elemental analysis: C 45.86, H 6.41, N 1.80 .

Oligocarbonate diols based on 1,6-bis(2-hydroxyethoxycarbonylamino)hexane was prepared in a similar method.

Synthesis of Urethane Prepolymer from Oligo(trimethylene carbonate)diol and IPDI

To a $250 \mathrm{~cm}^{3}$ round-bottomed flask equipped with a mechanical stirrer and thermometer, $6.66 \mathrm{~g}(0.03 \mathrm{~mol})$ of IPDI and $15 \mathrm{~g}(0.01 \mathrm{~mol})$ of oligo(trimethylene carbonate)diol $(1500 \mathrm{Da})$ were placed. The reaction mixture was stirred for $3 \mathrm{~h}$ at $85^{\circ} \mathrm{C}$ under nitrogen atmosphere. The reaction was carried out to a complete decay of the absorption band corresponding to the polyol OH groups in IR spectra. After reaction completion, the excess of IPDI was distilled off at the same temperature under reduced pressure $(2 \mathrm{mmHg})$ for $20 \mathrm{~min}$.

Elemental analysis: C 51.59, H 6.67, N 3.20.

\section{Curing of the Prepolymer with Water Vapor}

The obtained urethane prepolymers were poured into glass forms of $10 \times 10 \times 0.3 \mathrm{~cm} \times \mathrm{cm} \times \mathrm{cm}$ and placed in a climatic chamber at $50^{\circ} \mathrm{C}$ in air of $55 \%$ relative humidity. The curing process was monitored by means of IR spectroscopy observing the decay of the absorption band at $2260 \mathrm{~cm}^{-1}$ characteristic for urethane prepolymer isocyanate groups.

Studies of the Mechanical Properties of Poly(urethane-urea)s

Samples in the shape of dumbbells (type II) according to the standard PN-ENISO:527-1 and 2 were 


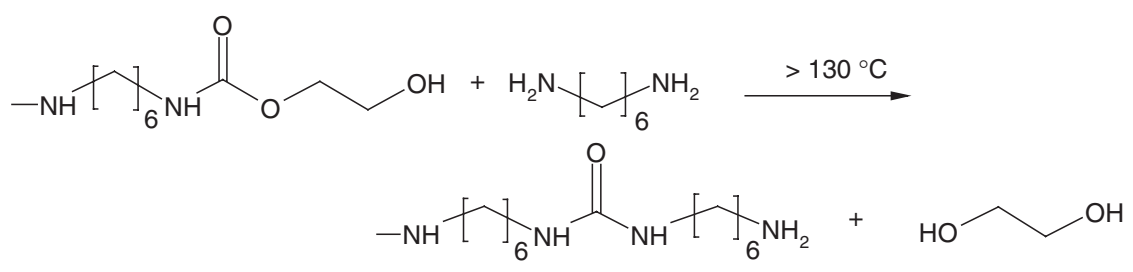

Scheme 2.

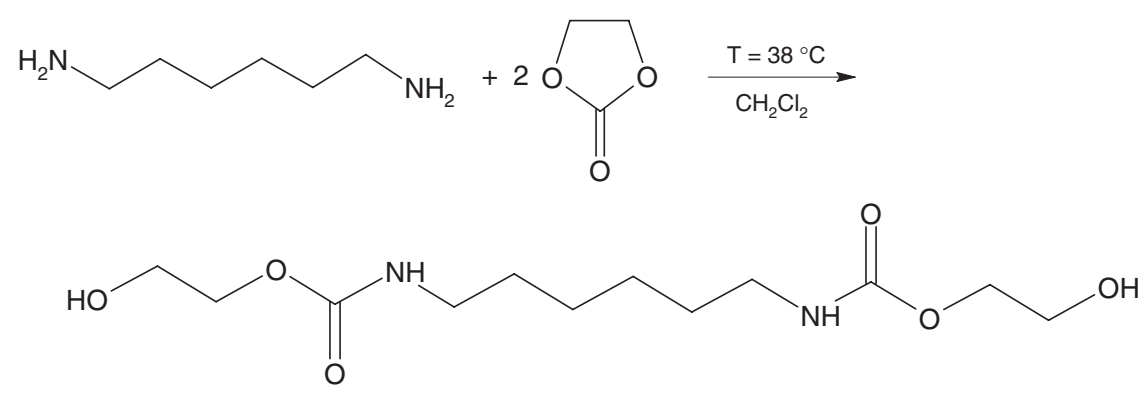

Scheme 3.

cut out from cured poly(urethane-urea) foils. Tensile testing was carried out with an Instron Model 5566 Universal Testing Machine. A $500 \mathrm{~N}$ load cell was used and the crosshead was $20 \mathrm{~mm} / \mathrm{min}$ (the distance between the holders was $80 \mathrm{~mm}$ ).

\section{RESULTS AND DISCUSSION}

\section{Synthesis of Trimethylene Carbonate (TMC)}

Trimethylene carbonate is usually obtained using ethyl chloroformate and 1,3-propanediol. ${ }^{17}$ In our approach this cyclic carbonate was synthesized without using phosgene or its derivatives. Zinc acetate was used as a catalyst for the reaction of obtaining trimethylene carbonate from dimethyl carbonate and 1,3-propanediol. This catalyst forms a homogeneous system with a mixture of reagents and linear oligocarbonatediol of molecular weight of $c a .1500$ can be prepared in the polycondensation step. The oligomers obtained were then subjected to additional transesterification at 130 to $240{ }^{\circ} \mathrm{C}$ under reduced pressure ( $2 \mathrm{mmHg}$ ) until TMC crystals appear in the distillate, i.e. to the moment when the depolymerization will be the dominating process with respect to the chain growth reaction due to the ester exchange. The depolymerization process combined with the monomer distillation was carried out at $230-235^{\circ} \mathrm{C} / 2 \mathrm{mmHg}$.

In comparison to known methods utilizing ethyl chloroformate ${ }^{17}$ or phosgene, ${ }^{18}$ this process is characterized by a high yield reaching $70 \%$, and crude TMC does not require multiple recrystallization. The fact that the reaction byproducts can be again utilized in the TMC synthesis is another advantage of this method.
Synthesis of $\alpha, \omega$-Bis(2-hydroxyethoxycarbonylamino)alkanes

The reaction of primary aliphatic amines with alkylene carbonate proceeds at room temperature with a relatively high yield, $80-85 \%$. On the other hand, if the reaction is carried out at a higher temperature (above $130^{\circ} \mathrm{C}$ ), urea groups may be formed (Scheme 2). ${ }^{19}$

It was found, that the application of methylene chloride as a solvent allowed to obtain a pure product with a yield of more than $90 \%$, irrespective of the diamine aliphatic chain length, when the reaction is carried out at $38^{\circ} \mathrm{C} .{ }^{20,21}$ The product precipitates from the methylene chloride solution and thus the reaction equilibrium is shifted in favor of the formed DHDU (Scheme 3).

\section{Polymerization of Trimethylene Carbonate (TMC)}

It was found that the TMC polymerization produces oligocarbonate diols of relatively narrow molecular weight distribution containing two terminal primary $\mathrm{OH}$ groups. The thermally initiated polymerization, using various initiators, as well as the enzymatic method using the Chirazyme L-2 lipase were applied.

\section{Polymerization Thermally Initiated}

Oligocarbonatediols based on trimethylene carbonate were obtained using 1,3-propanediol, 1,2-bis(2hydroxyethoxycarbonylamino)ethane, and 1,6-bis(2hydroxyethoxycarbonylamino)hexane as polymerization initiators. When changing the monomer to initiator molar ratio, polyols of molecular weights of 1500 and 2000 were obtained. The molecular weight of the oligomer was determined from the signal intensity ratio of protons derived from methylene groups 


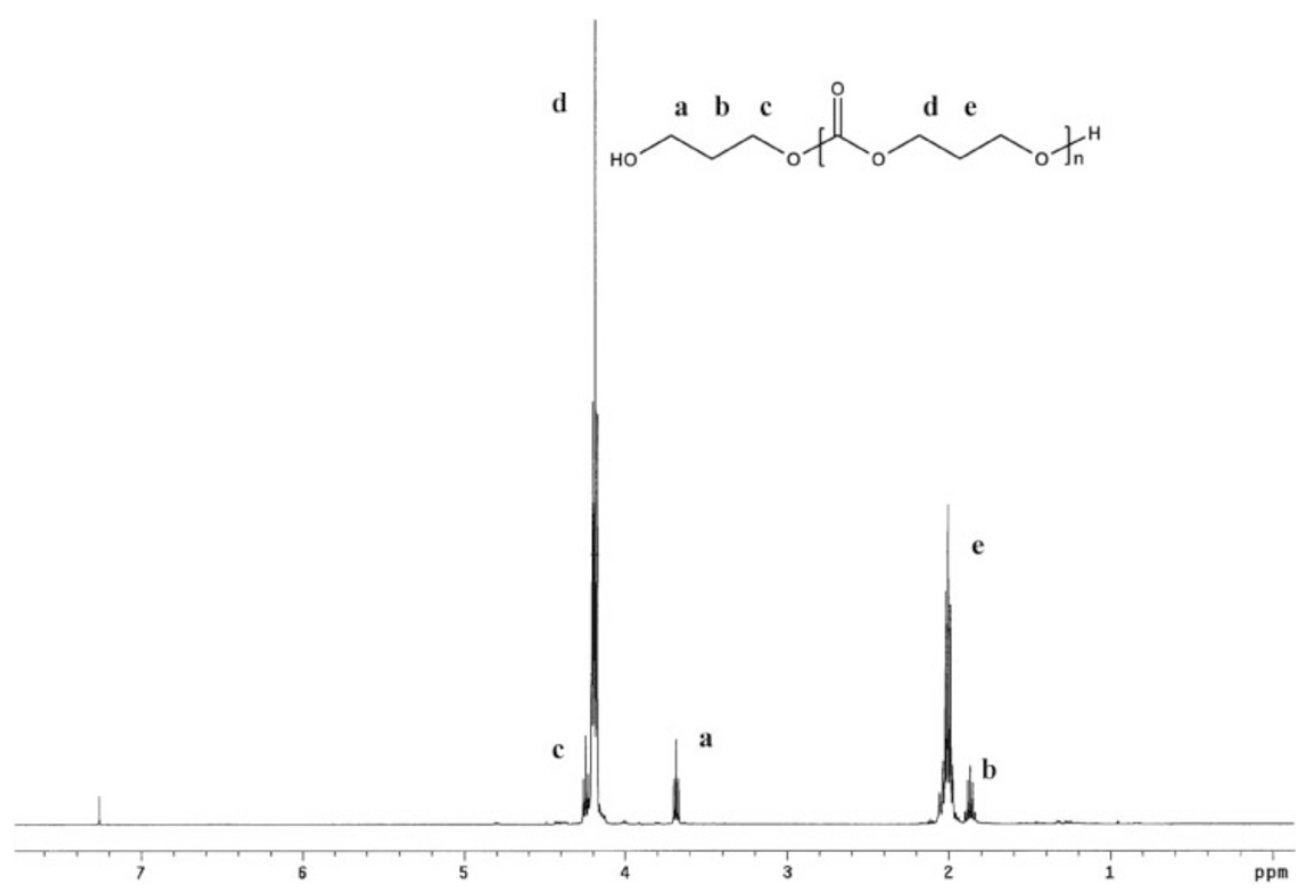

Figure 1. ${ }^{1} \mathrm{H}$ NMR spectrum $\left(400 \mathrm{MHz}, \mathrm{CDCl}_{3}\right.$ ) of oligocarbonate diol obtained by thermal polymerization trimethylene carbonate at $110^{\circ} \mathrm{C}$ in the presence of 1,3-propanediol as an initiator.

neighboring the carbonate groups to that of the methylene groups neighboring the $\mathrm{OH}$ terminal groups, in the ${ }^{1} \mathrm{H}$ NMR spectrum (Figure 1). The differences between the molecular weights calculated from the monomer to initiator molar ratio and those determined by the ${ }^{1} \mathrm{H}$ NMR method, were very small, which indicates a high purity of the monomer used. Long reaction time (over $24 \mathrm{~h}$ ) in the presence of diols suggests that this reaction is not a typical polymerization, but stepwise polyaddition. In the presence of a considerably large amount of the initiator with hydroxyl groups it is not possible to form an alkoxide anion, as was postulated by Kricheldorf. ${ }^{13}$ Transesterification between the cyclic carbonate and initiator takes place, and then the resultant oligocarbonatediol reacts with cyclic carbonate and a high molecular weight polymer is formed.

In the case of using 1,3-propanediol as an initiator, the oligocarbonatediol obtained has a regular structure. Only one series of peaks, differing from each other by $102 \mathrm{Da}$, is present in the MALDI-TOF mass spectrum (Figure 2). The application of $\alpha, \omega$-bis(2-hydroxyethoxycarbonylamino)alkane initiators allows a hard fragment consisting with two urethane groups derived from the initiator to be in-built into the oligocarbonate chain (Scheme 4). The presence of a hard segment in the oligomer increases considerably the glass transition temperature of oligocarbonatediol from $-46.1^{\circ} \mathrm{C}$ for the oligomer containing 1,3-propanediol to $-23.0^{\circ} \mathrm{C}$ for the oligomer with 1,2-bis(2hydroxyethoxycarbonylamino)ethane (Table I). This is caused by the formation of intermolecular hydrogen bonds of urethane groups derived from the DHDU initiator. In the FT IR spectrum of the oligomers containing DHDU (Figure 3) there are the absorption bands at $3545 \mathrm{~cm}^{-1}$ corresponding to $\mathrm{OH}$ groups and at 3470 $\mathrm{cm}^{-1}$ which can be assigned to NH groups of the hydrogen bonded urethane linkages. In the case of oligocarbonate diol without DHDU units the broaden absorption band of $\mathrm{OH}$ groups at $3365 \mathrm{~cm}^{-1}$ are observed. Higher glass transition temperatures were shown by oligomers containing initiators in which the urethane groups were separated from each other by two carbon atoms in the aliphatic chain $\left(-23.0^{\circ} \mathrm{C}\right)$, with respect to those separated by six carbon atoms $\left(-25.4^{\circ} \mathrm{C}\right)$. In the case of oligo(trimethylene carbonate)diol, as expected, the glass transition temperature rises with an increase in the molecular weight. ${ }^{22} \mathrm{~A}$ similar relationship was observed for oligomers containing DHDU initiators.

In the MALDI-TOF mass spectrum of the TMC polymerization product in the presence of 1,2-bis(2hydroxyethoxycarbonylamino)ethane two series of peaks are present. The first series of signals of greater intensity can be assigned to oligocarbonatediols with one incorporated initiator molecule (Figure 4).

The difference between subsequent signals is $102 \mathrm{Da}$, which corresponds to the molecular weight of a trimethylene carbonate monomeric unit. The macromolecules are terminated with hydroxyl groups (residual mass $30 \mathrm{Da}$ ). The second series of signals of lesser intensity can be assigned to oligocarbonatediols 


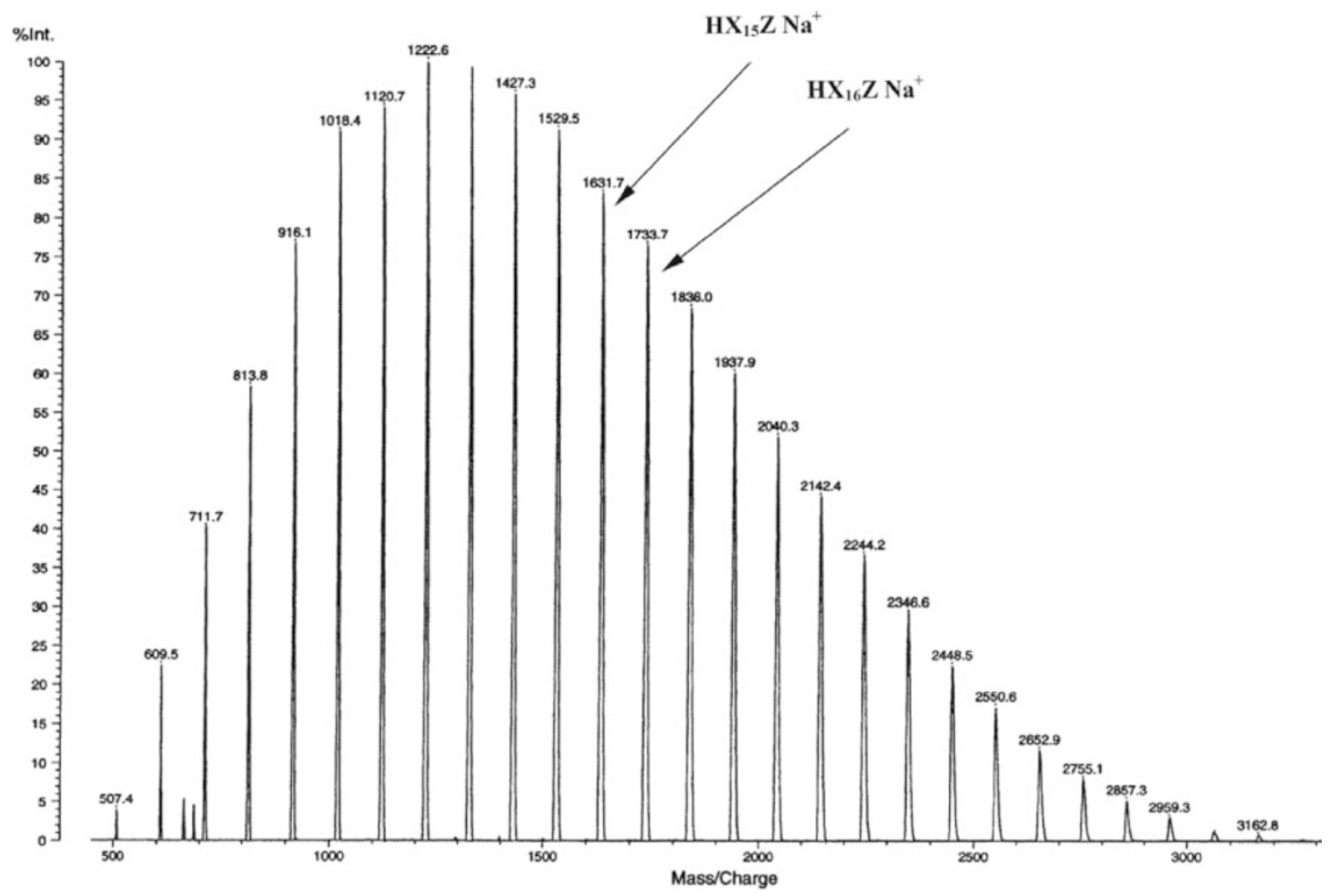

Figure 2. MALDI-TOF mass spectrum of oligocarbonatediol obtained by thermal polymerization trimethylene carbonate at $110^{\circ} \mathrm{C}$ in the presence of 1,3-propanediol as an initiator.

where: $\mathrm{X}=\mathrm{OCH}_{2} \mathrm{CH}_{2} \mathrm{CH}_{2} \mathrm{OC}(\mathrm{O}), \mathrm{Z}=\mathrm{OCH}_{2} \mathrm{CH}_{2} \mathrm{CH}_{2} \mathrm{OH}$.

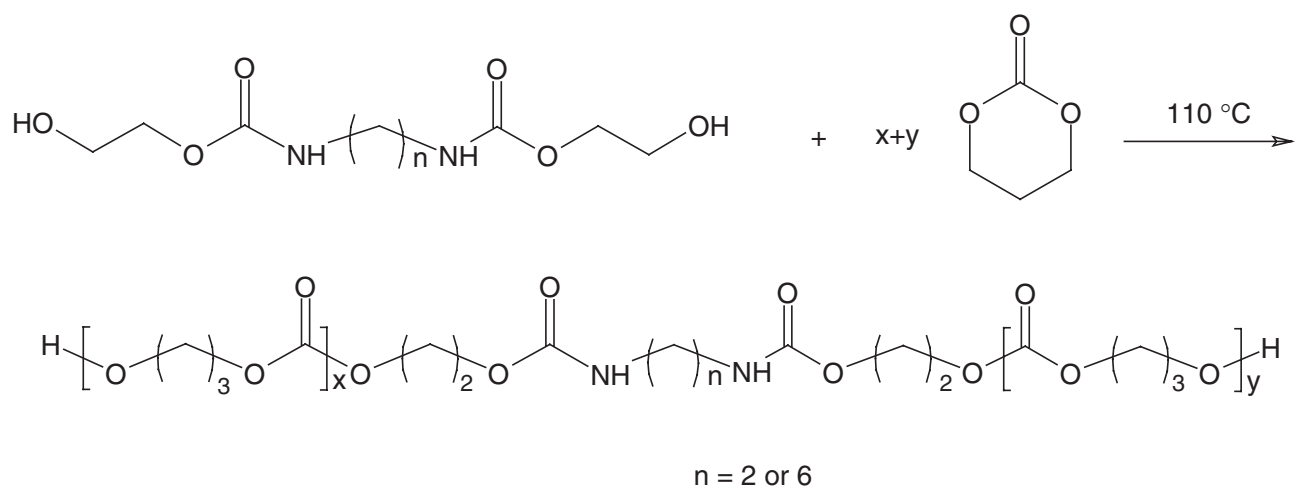

Scheme 4.

Table I. Influence of chemical structure and molecular weight of oligo(trimethylene carbonate)s containing DHDU hard segments on glass transition temperature

\begin{tabular}{|c|c|c|c|c|c|c|c|c|}
\hline \multirow{2}{*}{ Lp. } & \multirow{2}{*}{ Initiator } & \multirow{2}{*}{$\begin{array}{l}\text { TMC/initiator } \\
(\mathrm{mol} / \mathrm{mol})\end{array}$} & \multirow{2}{*}{$\begin{array}{l}M_{\mathrm{n}} \text { calculated from } \\
\mathrm{TMC} / \text { initiator ratio } \\
\text { (Da) }\end{array}$} & \multirow{2}{*}{$\begin{array}{c}M_{\mathrm{n}} \text { determined } \\
\text { from }{ }^{1} \mathrm{HNMR} \\
\text { (Da) }\end{array}$} & \multicolumn{2}{|c|}{ MALDI-TOF } & \multirow{2}{*}{$\begin{array}{l}\text { Urethane group } \\
\text { content } \\
\text { (wt. \%) }\end{array}$} & \multirow{2}{*}{$\begin{array}{c}T_{\mathrm{g}} \\
\left({ }^{\circ} \mathrm{C}\right)\end{array}$} \\
\hline & & & & & $M_{\mathrm{n}}$ & $M_{\mathrm{w}} / M_{\mathrm{n}}$ & & \\
\hline 1 & $1,3-\mathrm{PD}^{\mathrm{a})}$ & $14.2 / 1$ & 1520 & 1500 & 1600 & 1.21 & 0 & -46.1 \\
\hline 2 & $1,3-\mathrm{PD}$ & $19 / 1$ & 2020 & 1990 & 2150 & 1.24 & 0 & -43.2 \\
\hline 3 & 1,2-DHDU ${ }^{\mathrm{b})}$ & $12.8 / 1$ & 1540 & 1490 & 1580 & 1.27 & 8.1 & -23.0 \\
\hline 4 & 1,2-DHDU & $18 / 1$ & 2070 & 2020 & 1880 & 1.27 & 5.9 & -21.8 \\
\hline 5 & 1,6-DHDUc) & $12 / 1$ & 1520 & 1480 & 1640 & 1.31 & 8.1 & -25.4 \\
\hline 6 & 1,6-DHDU & $17 / 1$ & 2030 & 1980 & 2220 & 1.29 & 6.1 & -24.5 \\
\hline
\end{tabular}

a) 1,3-PD: 1,3-propanediol. b) 1,2-DHDU: 1,2-bis(2-hydroxyethoxycarbonylamino)ethane. ${ }^{\text {c) }}$ 1,6-DHDU: 1,6-bis(2-hydroxyethoxycarbonylamino)hexane. 


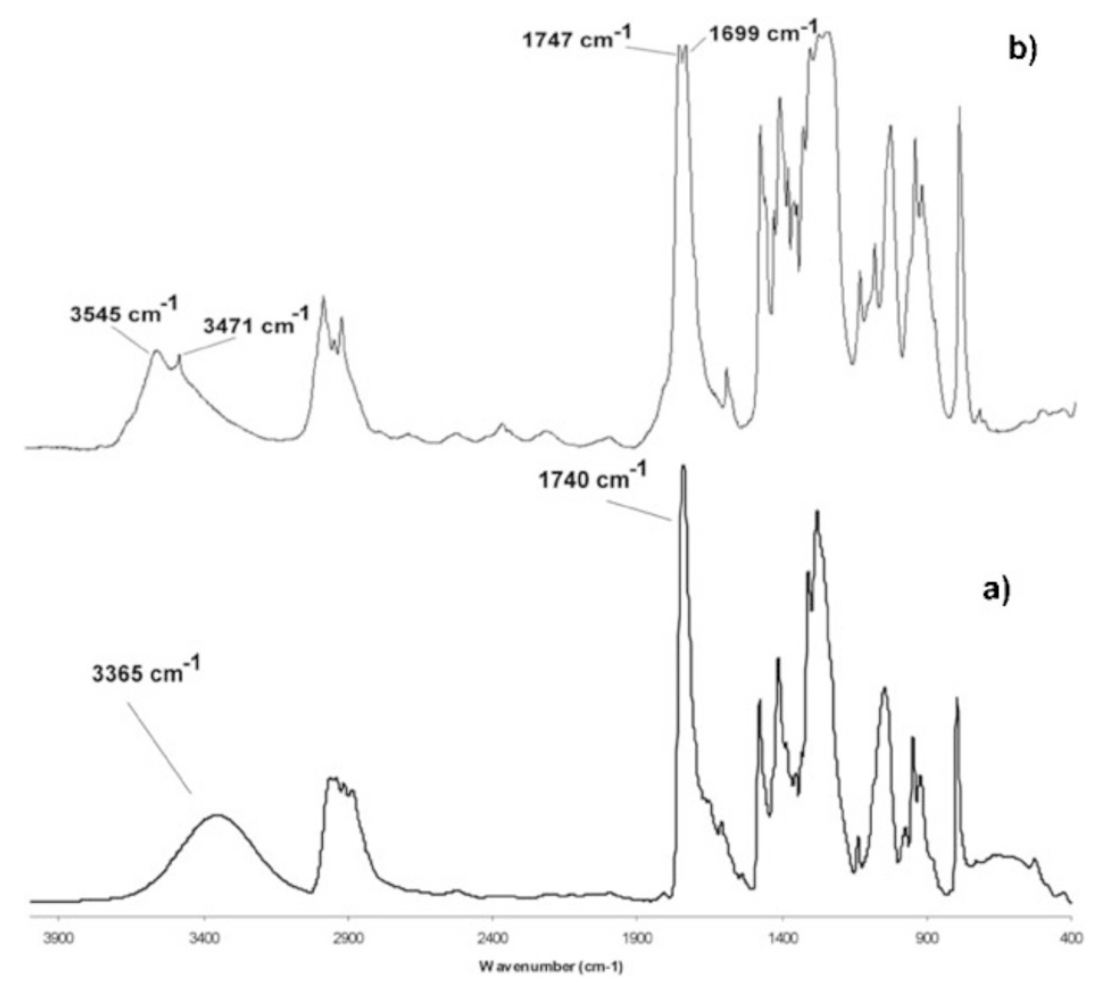

Figure 3. FT IR spectra of oligomers obtained by trimethylene carbonate polymerization initiated with 1,3-propanediol (a) and 1,2bis(2-hydroxyethoxycarbonylamino)ethane (b).

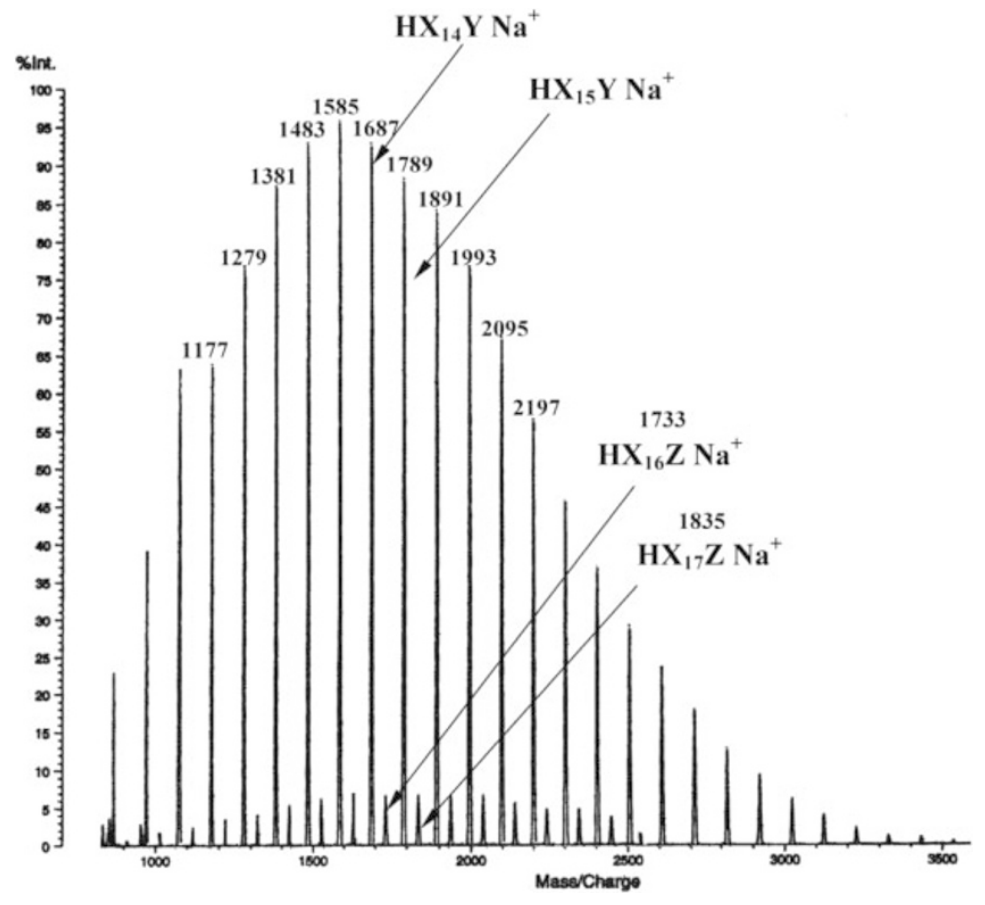

Figure 4. MALDI-TOF mass spectrum of oligocarbonatediol obtained by thermal polymerization of trimethylene carbonate at $110{ }^{\circ} \mathrm{C}$ in the presence of 1,2-bis(2-hydroxyethoxycarbonylamino)ethane as an initiator.

where: $\mathrm{X}=\mathrm{OCH}_{2} \mathrm{CH}_{2} \mathrm{CH}_{2} \mathrm{OC}(\mathrm{O}), \mathrm{Y}=\mathrm{OCH}_{2} \mathrm{CH}_{2} \mathrm{OC}(\mathrm{O}) \mathrm{NH}\left(\mathrm{CH}_{2}\right)_{2} \mathrm{NHC}(\mathrm{O}) \mathrm{OCH}_{2} \mathrm{CH}_{2} \mathrm{OH}, \mathrm{Z}=\mathrm{OCH}_{2} \mathrm{CH}_{2} \mathrm{CH}_{2} \mathrm{OH}$.

resulting from the polymerization of TMC in the presence of traces of 1,3-propanediol. The lack of signals derived from macromolecules comprising two units of the initiator indicates that no exchange reaction between linear macrodiols occurs. The products of
TMC polymerization irrespective of the initiator used are characterized by a small molecular weight distribution and the polydispersity does not exceed 1.24 (Table II). 
Poly(urethane-urea)s Based on Oligocarbonatediols

Table II. Characteristics of oligo(trimethylene carbonate)s obtained by different polymerization methods

\begin{tabular}{|c|c|c|c|c|c|c|}
\hline \multirow{2}{*}{$\begin{array}{l}\text { Polymerization } \\
\text { method }\end{array}$} & \multirow{2}{*}{$\begin{array}{c}\text { Temperature } \\
\left({ }^{\circ} \mathrm{C}\right)\end{array}$} & \multirow{2}{*}{$\begin{array}{l}\text { Reaction time } \\
\text { (min) }\end{array}$} & \multirow{2}{*}{$\begin{array}{c}\text { TMC conversion } \\
(\%)\end{array}$} & \multirow{2}{*}{$\begin{array}{c}M_{\mathrm{n}} \text { determined } \\
\text { from }{ }^{1} \mathrm{H} \mathrm{NMR} \\
\text { (Da) }\end{array}$} & \multicolumn{2}{|c|}{ MALDI-TOF } \\
\hline & & & & & $M_{\mathrm{n}}$ & $M_{\mathrm{w}} / M_{\mathrm{n}}$ \\
\hline \multirow{3}{*}{ Thermal } & 110 & 1560 & 97 & $1500^{\mathrm{a})}$ & 1600 & 1.21 \\
\hline & 110 & 1650 & 98 & $1990^{\mathrm{b})}$ & 2150 & 1.24 \\
\hline & 40 & 7200 & 65 & 1400 & 1490 & 1.37 \\
\hline \multirow[t]{3}{*}{ Enzymatic } & 60 & 6000 & 75 & 1650 & 1950 & 1.33 \\
\hline & 80 & 4320 & 77 & 1600 & 1920 & 1.35 \\
\hline & ca. 120 & 10 & 90 & $1300^{\mathrm{a})}$ & 1450 & 1.52 \\
\hline \multirow[t]{2}{*}{ In a microwave oven } & ca. 120 & 15 & 75 & $1150^{\mathrm{a})}$ & 1220 & 1.71 \\
\hline & ca. 120 & 15 & 92 & $1750^{\mathrm{b})}$ & 1890 & 1.66 \\
\hline
\end{tabular}

a) Polymerization initiated with 1,3-propanediol for the molar ratio monomer/initiator: 14.2:1; ${ }^{\text {b) }}$ Polymerization initiated with 1,3-propanediol for the molar ratio monomer/initiator: 19:1.

\section{Polymerization in a Microwave Oven}

Microwave irradiation is well known to have a significant effect on the rate of various chemical reactions. This process exploits mainly the microwave volumetric heating effect. ${ }^{23}$ The fundamental difference between microwave and conventional heating is that in conventional heating heat transfer occurs from the heating device to the medium, while in microwave heating heat is dissipated inside the irradiated medium. It was found that the polymerization of TMC carried out in a microwave oven proceeds with a much greater rate in comparison with the thermal method. It only took $10 \mathrm{~min}$ to obtain an oligomer of molecular weight about 1300. The monomer conversion reached 90\% (Table II). Also in this case the product obtained was a polycarbonate terminated with $\mathrm{OH}$ groups without ether bonds. In the MALDI-TOF mass spectrum of the product obtained in a microwave oven only one set of peaks is present. The macromolecules are terminated with hydroxyl groups of 1,3-propanediol (residual mass: 76 Da). Under such reaction conditions the formation of macrocycles was not observed.

The action of microwave irradiation on chemical reactions is still unsolved. There is no proof that the irradiation induces microwave activation (a non-thermal effect). The higher reaction rate can be associated with 'superheating effect' described by Baghurst and Mingos. ${ }^{24} \mathrm{~A}$ rather poor reproducibility of the results in our case can be explained by the lack of stirring, presence of water in crude monomers or lack of boiling nucleants.

\section{Polymerization in the Presence of Lipase}

The enzymatic polymerization of trimethylene carbonate was carried out using lipase immobilized on a polymeric matrix (Chirazyme L-2) in a solvent (THF) at $60{ }^{\circ} \mathrm{C}$.

A product not containing ether groups was obtained under mild conditions and no formation of macrocycles was observed. One series of peaks differing in molar mass by $102 \mathrm{Da}$ is present in the MALDITOF mass spectrum of the product resulting from the trimethylene carbonate polymerization. The average molecular weight was 1650 . However, peaks of small intensity not forming a series of signals are also present in the spectrum. They are probably derived from oligomers with one hydroxyl group protected by lipase aminoacid residuals.

The low monomer conversion, long reaction time (Table II) and the presence of macromolecules with one protected hydroxyl group are the main flaws of this method.

Taking the above into consideration, further steps of obtaining poly(urethane urea)s were carried out using oligocarbonatediols obtained by the thermal polymerization method.

Synthesis of Urethane Prepolymers with Oligo(trimethylene carbonate)s and Isophoronodiisocyanate (IPDI)

The synthesis of urethane prepolymers was carried out at $85^{\circ} \mathrm{C}$ using oligocarbonatediols of molecular weight 1500 and 2000 obtained with 1,3-propanediol and DHDUs as initiators. The reaction progress was monitored by means of infrared spectroscopy and was carried out to the decay of the $\mathrm{OH}$ group absorption band $\left(3300 \mathrm{~cm}^{-1}\right)$ (Figure 5).

The reaction course is presented in Scheme 5 (only one of the three possible structures is presented). In the urethane prepolymer synthesis the different reactivity of the isocyanate groups in IPDI is utilized. The isocyanate groups present at the secondary carbon atom are more reactive and they first react with the oligocarbonatediol $\mathrm{OH}$ groups. The application of a three-fold molar excess of the isocyanate group with respect to the polyol suppresses the chain elongation reaction, lowering the probability of reaction of the second IPDI isocyanate group. The unreacted isophoronodiisocyanate causes a decrease in the viscosity of the system, which facilitates the polymer pro- 


\section{P. PAWŁOWSKI et al.}

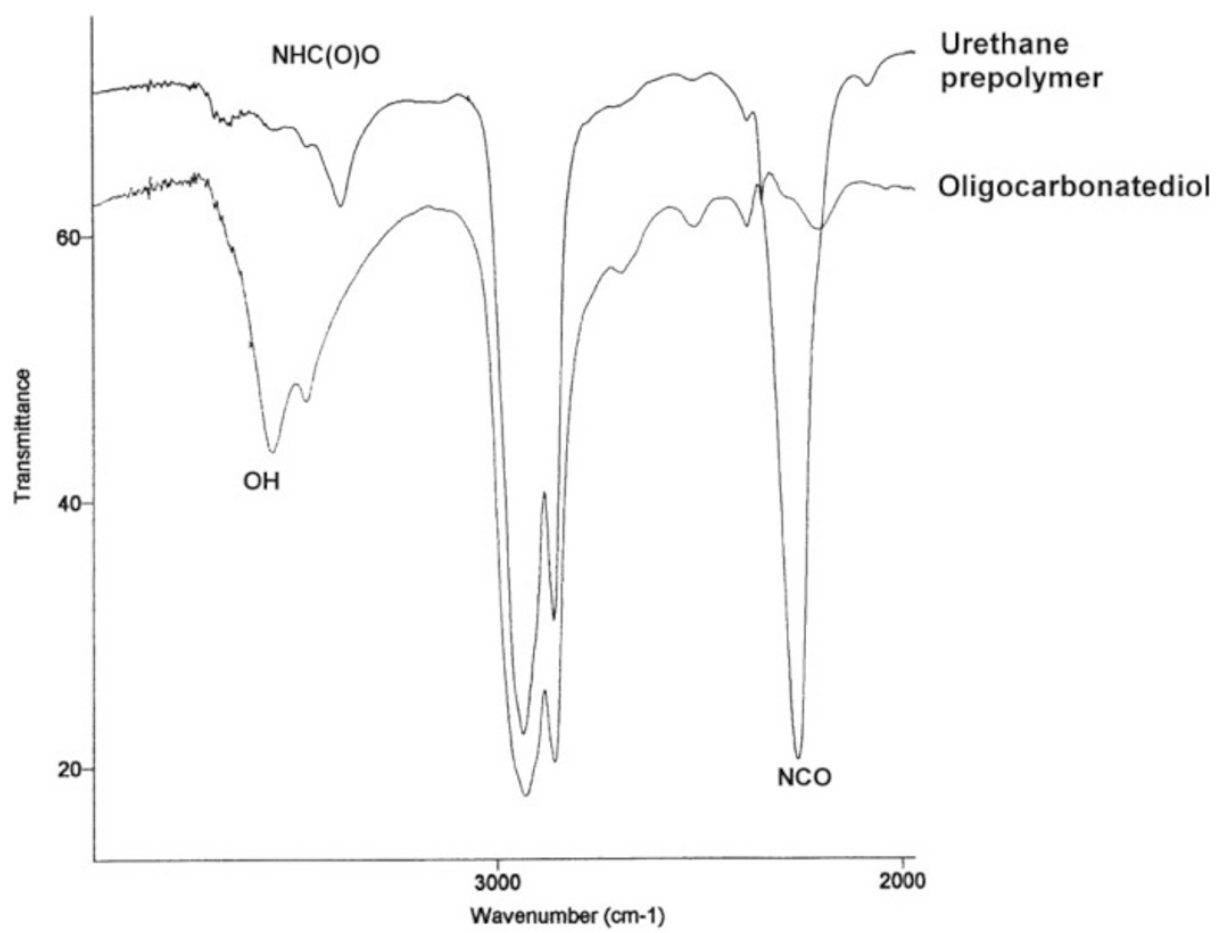

Figure 5. Fragment of FT IR spectrum of urethane prepolymer obtained in the reaction of oligocarbonatediol with IPDI at $85{ }^{\circ} \mathrm{C}$.

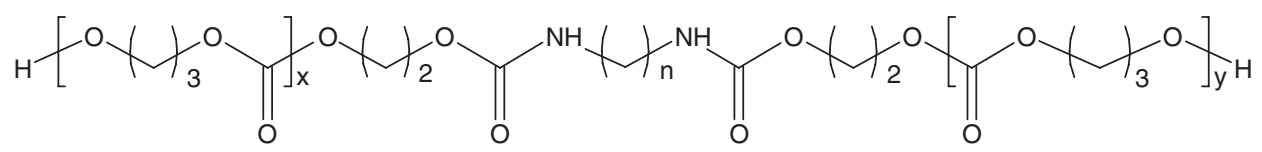<smiles>CC1(C)CC([N+](=O)[O-])CC(C)(C=O)C1</smiles>
$\mathrm{T}=85^{\circ} \mathrm{C}$

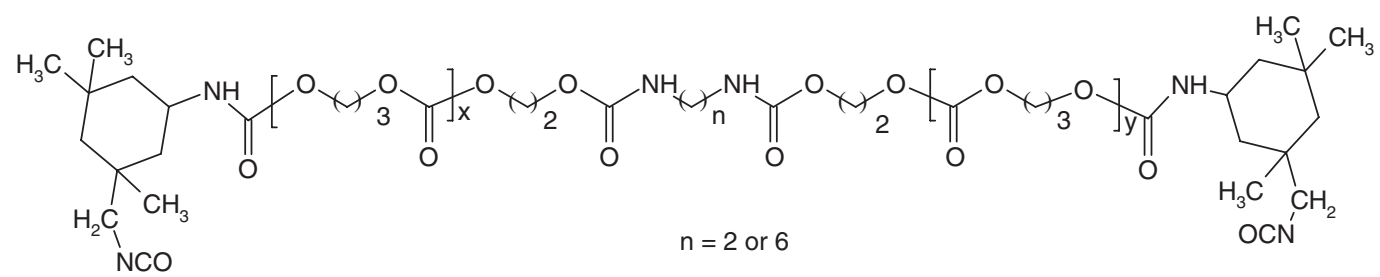

Scheme 5.

cessing, but is unfavorable due to the stiffness of short urea fragments resulting from the reaction with water. Therefore, the excess of isocyanate was removed at $85^{\circ} \mathrm{C}$ under reduced pressure $(2 \mathrm{mmHg})$.

Synthesis of Urethane Prepolymer from Oligo(trimethylene carbonate)diol and IPDI with the Addition of 1,6-Bis(2-hydroxyethoxycarbonylamino)hexane

The urethane prepolymers were obtained under conditions analogous to those described above using 1,6-bis(2-hydroxyethoxycarbonylamino)hexane as a pseudo-chain extender (Table III). The urethane prepolymers obtained from the reaction of IPDI with oligo(trimethylene carbonate)diol and DHDU have a different structure than those described above. In the post-reaction mixture molecules of small molecular weight are present besides the oligocarbonatediol molecules terminated with $\mathrm{NCO}$ groups derived from IPDI. They are formed in the reaction of DHDU with IPDI (Scheme 6). After curing, these fragments are 
Poly(urethane-urea)s Based on Oligocarbonatediols

Table III. Mechanical properties of poly(urethane-urea)s obtained from oligomerols containing DHDU (DHDU) hard segments

\begin{tabular}{|c|c|c|c|c|c|c|c|}
\hline Initiator & $\begin{array}{c}\text { Molar ratio } \\
\mathrm{OCD}^{\mathrm{a})} / \mathrm{DHDU}\end{array}$ & $\begin{array}{c}M_{\mathrm{n}} \text { of } \\
\text { oligomerol }\end{array}$ & $\begin{array}{c}\text { Elongation } \\
\text { at break } \\
(\%)\end{array}$ & $\begin{array}{l}\text { Tensile } \\
\text { strength } \\
(\mathrm{MPa})\end{array}$ & $\begin{array}{c}\text { Stress at } 100 \% \\
\text { of elongation } \\
(\mathrm{MPa})\end{array}$ & $\begin{array}{c}\text { Shore } \\
\text { hardness } \\
\left({ }^{\circ} \mathrm{ShA}\right)\end{array}$ & $\begin{array}{l}T_{\mathrm{g}} \\
\left({ }^{\circ} \mathrm{C}\right)\end{array}$ \\
\hline 1,3-propanediol & - & 1500 & $750 \pm 12$ & $35.2 \pm 0.5$ & $4.9 \pm 0.4$ & 81 & -19.7 \\
\hline 1,3-propanediol & - & 1990 & $890 \pm 22$ & $14.5 \pm 1$ & $2.5 \pm 0.5$ & 76 & -21.3 \\
\hline $\begin{array}{l}\text { 1,2-bis(2-hydroxyethoxy- } \\
\text { carbonylamino)ethane }\end{array}$ & - & 1490 & $630 \pm 25$ & $40.3 \pm 2$ & $6.6 \pm 1.0$ & 89 & 7.4 \\
\hline $\begin{array}{l}\text { 1,2-bis(2-hydroxyethoxy- } \\
\text { carbonylamino)ethane }\end{array}$ & - & 2020 & $800 \pm 12$ & $24.2 \pm 3$ & $3.0 \pm 0.6$ & 88 & 0.2 \\
\hline $\begin{array}{l}\text { 1,6-bis(2-hydroxyethoxy- } \\
\text { carbonylamino)hexane }\end{array}$ & - & 1480 & $430 \pm 11$ & $49.8 \pm 5$ & $6.8 \pm 1.3$ & 93 & 0.5 \\
\hline $\begin{array}{l}\text { 1,6-bis(2-hydroxyethoxy- } \\
\text { carbonylamino)hexane }\end{array}$ & - & 1980 & $580 \pm 18$ & $45.5 \pm 2$ & $6.0 \pm 1.2$ & 90 & -1.3 \\
\hline 1,3-propanediol & $5 / 1^{b)}$ & 1500 & $244 \pm 10$ & $58.8 \pm 0.5$ & $24.3 \pm 0.8$ & 75 & - \\
\hline 1,3-propanediol & $2 / 1^{b)}$ & 1500 & $189 \pm 10$ & $52.3 \pm 1$ & $31.3 \pm 0.6$ & 72 & - \\
\hline
\end{tabular}

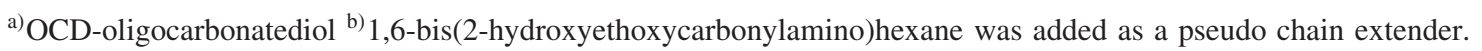

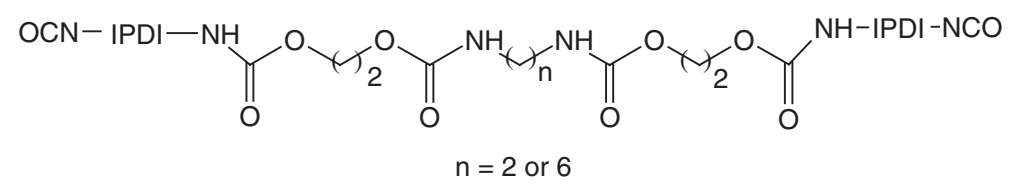

Scheme 6.

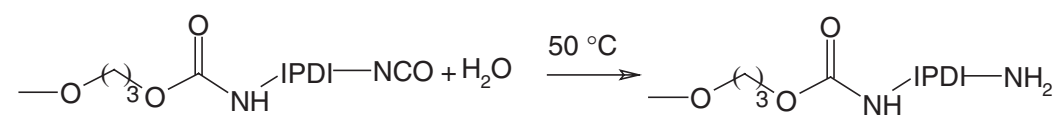

Scheme 7.

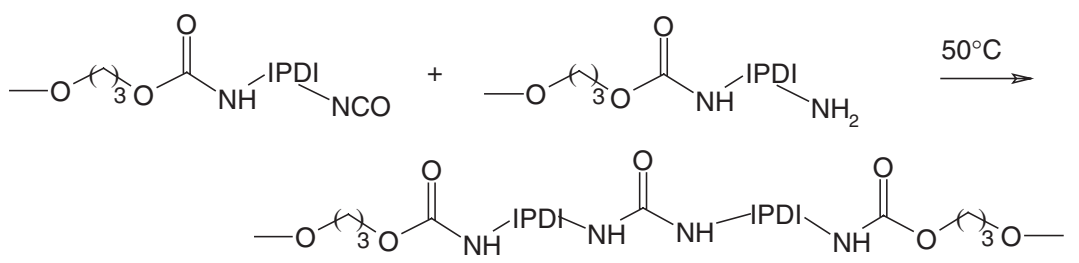

Scheme 8.

characterized by considerable stiffness due to the high concentration of urethane groups.

\section{Curing of Urethane Prepolymers with Water Vapor}

The curing of urethane prepolymers was carried out at $50{ }^{\circ} \mathrm{C}$ in a climatic chamber in air of $55 \%$ relative humidity. Under such conditions carbon dioxide formed as the reaction product of the isocyanate groups and $\mathrm{H}_{2} \mathrm{O}$ does not cause foaming of the foil (Scheme 7). The amine groups formed from the hydrolysis of the isocyanate groups react in high rate with the isocyanate ones forming urea groups (Scheme 8).

The reaction rate of isocyanate groups with the amine ones is much higher than that with water, which causes the isocyanate groups to react first of all with amine groups formed leading to high molecular weights of poly(urethane-urea). The curing time was about $120 \mathrm{~h}$. The poly(urethane urea) foils thus obtained are colorless and are characterized by a high transparency.

In Table III the mechanical properties of the elastomer films are presented.

Poly(urethane urea)s based on oligo(trimethylene carbonate) and IPDI are characterized by a high mechanical strength exceeding the strength of polyurethanes obtained from oligo(trimethylene carbonate) diol and MDI reported in (15).

The tensile strength of poly(urethane-urea)s depends on the molecular weight of the oligocarbonatediols used. Elastomers obtained from oligocarbonatediols of lower molecular weights exhibit a greater 


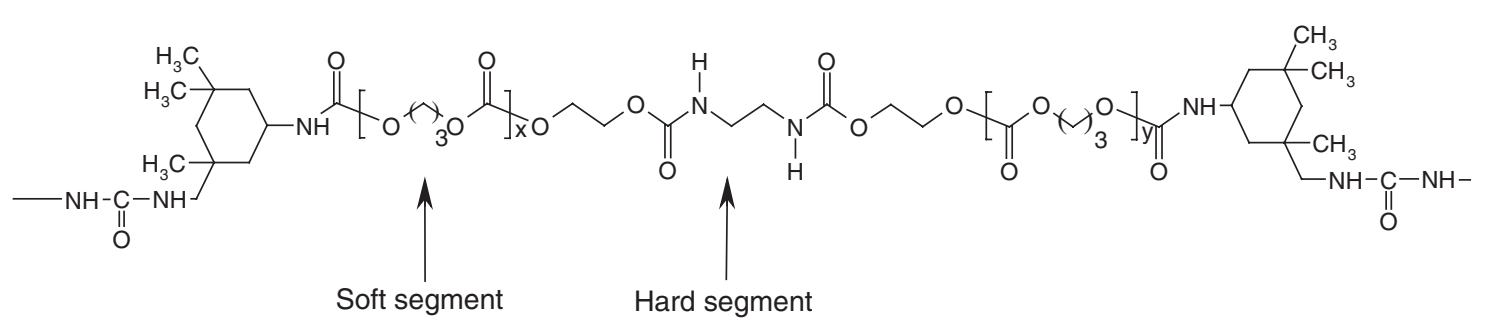

Scheme 9.

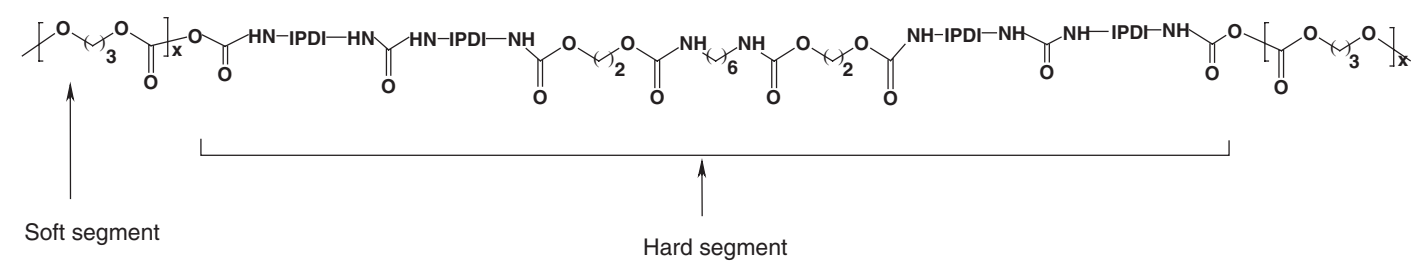

Scheme 10.

tensile strength (35.2 MPa) in comparison with those obtained from oligocarbonatediols of higher molecular weights $(14.5 \mathrm{MPa})$. This is due to a greater concentration of hard segments (urethane and urea units). However, the increase in molecular weight of the oligocarbonatediol by $500 \mathrm{Da}$ leads to an increase in elongation at break from 750 to $890 \%$. Similar relationships were observed for all poly(urethane-urea)s, irrespective of the oligocarbonatediol chemical structure (Table III).

Using oligocarbonatediols containing DHDU units leads to an increase in the tensile strength of poly(urethane-urea)s from 35.2 to $40.3 \mathrm{MPa}$ (Table III). This is caused by the introduction of two additional urethane groups in the molecule of the flexible oligocarbonate fragments and formation of additional hydrogen bonds between the polymer chains, which additionally stiffens the polymer structure (Scheme 9). However, elongation at break decreased from 750 to $630 \%$ when DHDU units were present in the polymer structure.

Elastomers containing 1,6-bis(2-hydroxyethoxycarbonylamino)hexane units exhibited higher tensile strength $(49.8 \mathrm{MPa})$ and lower elongation at break (430\%) than those containing 1,2-bis(2-hydroxyethoxycarbonylamino)ethane units (40.3 MPa and $630 \%$, respectively). This is due to shorter oligocarbonate fragments in the oligomerol molecules of the same molecular weight containing 1,6-bis(2-hydroxyethoxycarbonylamino)hexane units in comparison with those containing 1,2-bis(2-hydroxyethoxycarbonylamino)ethane units.

Also the elastomer shore hardness depends on the molecular weight of oligocarbonatediol and the presence of DHDU units. Shore hardness decreases from $81^{\circ} \mathrm{ShA}$ for the oligocarbonatediol molecular weight of 1500 to $76^{\circ} \mathrm{ShA}$ for the molecular weight of 1990 . The presence of 1,2-bis(2-hydroxyethoxycarbonylamino)ethane units in poly(urethane-urea) causes an increase in the shore hardness from 81 to $89^{\circ} \mathrm{ShA}$.

As can be expected, the glass transition temperature of poly(urethane-urea) elastomers also depends on the concentration of hard segments in the polymer chains. Poly(urethane-urea)s obtained from oligocarbonatediols of molecular weights about 1500 exhibit a higher glass transition temperature $\left(-19.7^{\circ} \mathrm{C}\right)$ in comparison with those of molecular weights of about 2000 $\left(-21.3^{\circ} \mathrm{C}\right)$. This relationship concerns all poly(urethane-urea)s, irrespective of the initiator unit present in the oligocarbonate chains. The presence of DHDU units causes a considerable increase in the glass transition temperature of poly(urethane-urea)s $\left(7.4^{\circ} \mathrm{C}\right.$ for 1,2-bis(2-hydroxylethoxycarbonylamino)ethane and $0.5^{\circ} \mathrm{C}$ for 1,6-bis(2-hydroxylethoxycarbonylamino)hexane) in comparison with elastomers comprising 1,3-propanediol units $\left(-19.7^{\circ} \mathrm{C}\right)$ (Table III).

The comparison of the mechanical properties of poly(urethane-urea)s obtained in the reaction of IPDI with oligocarbonatediol (molecular weight 1500) and 1,6-bis(2-hydroxyethoxycarbonylamino)hexane, used as a pseudo-chain extender, shows a drop in the elongation at break. For elastomers, in which the molar ratio of oligocarbonatediol to DHDU is $5: 1$, the elongation at break decreases from 750 to $244 \%$, and for the $2: 1$ ratio to $189 \%$ (Table III). This indicates a considerable stiffening effect of the $\alpha, \omega$-bis(2-hydroxyethoxycarbonyloamino)alkane. However, the tensile strength increases remarkably. When $16.7 \mathrm{~mol} \%$ of DHDU was used, an increase in the tensile strength from 35.2 to $58.5 \mathrm{MPa}$ was observed. A higher amount of DHDU leads to a smaller increase in the tensile strength. A similar relationship was observed 
for the modulus of elasticity of poly(urethane-urea)s.

The high strength of the thus obtained elastomers can be explained by the formation of large hard segments consisting of an array of 6 urethane and 2 urea groups (Scheme 10).

\section{CONCLUSIONS}

It has been shown that the use of DHDUs as initiators in trimethylene carbonate polymerization causes a considerable improvement in the mechanical strength of poly(urethane-urea)s when obtained from oligo(trimethylene carboanate)diols and IPDI as opposed to using 1,3-propanediol as a polymerization initiator. The application of $\alpha, \omega$-bis(2-hydroxyethoxycarbonyloamino)alkanes causes that urethane groups obtained by the non-isocyanate reaction pathway capable to form hydrogen bonds are additionally present in the poly(urethane-urea) molecules. The obtained poly(urethane-urea) foils exhibit very good mechanical properties, they are colorless and transparent. They do not contain toxic catalysts and could be applied in medicine as biocompatible material.

Acknowledgment. This paper is based upon work supported by the Polish State Committee for Scientific Research (7 09B 066 21) and Warsaw University of Technology (504/G/1020/0492).

\section{REFERENCES}

1. R. J. Zdrahala, J. Biomater. Appl., 11, 37 (1996).

2. K. Stokes, R. McVenes, and J. M. Anderson, J. Biomater. Appl., 9, 321 (1995).

3. R. F. Harris, J. Appl. Polym. Sci., 38, 463 (1998).

4. R. F. Storey and D. C. Hoffman, Macromolecules, 25, 5369
(1992)

5. W. Kuran, M. Listoś, T. Listoś, C. Dębek, and Z. Florjańczyk, Polymer, 41, 8531 (2000).

6. W. Kuran, Macromol. Chem. Phys., 195, 401 (1994).

7. W. Kuran and T. Listoś, Polimery, 37, 15 (1992).

8. R. W. Hergenrother, H. D. Wabers, and S. L. Cooper, Biomaterials, 14, 449 (1993).

9. G. Rokicki, Prog. Polym. Sci., 25, 259 (2000).

10. M. Murayama, F. Sanda, and T. Endo, Macromolecules, 31, 919 (1998).

11. H. R. Kricheldorf, I. Kreiser-Sanders, and C. Boettcher, Polymer, 36, 1253 (1995).

12. H. R. Kricheldorf and A. Mahler, J. Macromol. Sci., Pure Appl. Chem., A33, 821 (1996).

13. H. R. Kricheldorf, S.-R. Lee, and B. Weegen-Schulz, Macromol. Chem. Phys., 197, 1043 (1997).

14. S. Kobayashi, H. Kikuchi, and H. Uyama, Macromol. Rapid Commun., 18, 575 (1997).

15. T. C. Forschner, W. H. Boon, A. Sendijarevic, K. C. Frisch, and D. E. Gwyn, U.S. Patent 6593444 (2003); Chem. Abstr., 135, 274107 v (2001).

16. G. Rokicki and P. Pawłowski, Polish Patent Application P.362641 (2003).

17. T. Ariga, T. Takata, and T. Endo, Macromolecules, 30, 737 (1997).

18. M. P. Bowman and C. B. Kreutzberger, U. S. Patent 6506 909 (2003), Chem. Abstr., 138, 73719 u (2003).

19. T. Burgel and M. Fedtke, Polym. Bull., 27, 171 (1991).

20. G. Rokicki and A. Piotrowska, Polymer, 43, 2927 (2002).

21. H. J. Assumption and L. J. Mathias, Polymer, 44, 5131 (2003).

22. P. R. Couchman, Polym. Eng. Sci., 21, 377 (1981).

23. H. M. Skip Kingston and S. J. Hanswell, Ed., "MicrowaveEnhanced Chemistry: Fundamentals, Sample Preparation and Application," American Chemical Society, Washington, 1997.

24. D. R. Baghurst and D. M. P. Mingos, J. Chem. Soc., Chem. Commun., 9, 674 (1992). 